\title{
Herbivore insects and predatory arthropods in freshwater swamp rice field in South Sumatra, Indonesia sprayed with bioinsecticides of entomopathogenic fungi and abamectin
}

\author{
SITI HERLINDA ${ }^{1,2,3, \bullet}$, GHANNI PRABAWATI ${ }^{3}$, YULIA PUJIASTUTI ${ }^{1,2,3}$, SUSILAWATI $^{4}$, TILI KARENINA ${ }^{5}$, \\ HASBI $^{2,6}$, CHANDRA IRSAN ${ }^{1,2,3}$ \\ ${ }^{1}$ Department of Plant Pests and Diseases, Faculty of Agriculture, Universitas Sriwijaya. Jl. Raya Palembang-Prabumulih Km 32, Indralaya, Ogan Ilir \\ 30662, South Sumatra, Indonesia. Tel.: +62-711-580663, Fax.: +62-711-580276, "email: sitiherlinda@unsri.ac.id, \\ ${ }^{2}$ Research Center for Sub-optimal Lands, Universitas Sriwijaya. J1. Padang Selasa No. 524, Bukit Besar, Palembang 30139, South Sumatra, Indonesia \\ ${ }^{3}$ Crop Sciences Graduate Program, Faculty of Agriculture, Universitas Sriwijaya. J1. Padang Selasa No. 524, Bukit Besar, Palembang 30139, South \\ Sumatra, Indonesia \\ ${ }^{4}$ Department of Agronomy, Faculty of Agriculture, Universitas Sriwijaya. Jl. Raya Palembang-Prabumulih Km 32, Indralaya, Ogan Ilir 30662, South \\ Sumatra, Indonesia \\ ${ }^{5}$ Research and Development Agency of South Sumatra Province. Palembang 30136, South Sumatra, Indonesia \\ ${ }^{6}$ Department of Agricultural Engineering, Faculty of Agriculture, Universitas Sriwijaya, Indralaya, Ogan Ilir 30662, South Sumatra, Indonesia
}

Manuscript received: 6 June 2020. Revision accepted: 25 July 2020.

\begin{abstract}
Herlinda S, Prabawati G, Pujiastuti Y, Susilawati, Karenia T, Hasbi, Irsan C. 2020. Herbivore insects and predatory arthropods in freshwater swamp rice field in South Sumatra, Indonesia sprayed with bioinsecticides of entomopathogenic fungi and abamectin. Biodiversitas 21: 3755-3768. Herbivore insect population and predatory arthropods in rice field may be effected by the application entomopathogenic fungi or synthetic insecticide. The objective of this research was to analyze individual quantity of herbivore insects and predatory arthropod inhabiting freshwater swamp rice fields treated with bioinsecticides and abamectin (commercial insecticide). This research was conducted in the freshwater swamp rice field located in Village Pelabuhan Dalam, Sub District Pemulutan, District Ogan Ilir, and South Sumatra. The experiment was arranged in a Completely Randomized Block Design consisted of four plots of treatment. The research used the bioinsecticides made from entomopathogenic fungi (Beauveria bassiana, Metarhizium anisopliae, and Cordyceps military), and abamectin. Sampling to collect arthropods inhabiting rice canopy was also conducted using an entomological net in the study locations. This research found 12 families of herbivore insects with 22 species dominated by Nilaparvata lugens and Leptocorisa acuta and 32 species of spider belonged to eight families dominated by Tetragnatha virescens and Oxyopes matiensis. The species diversity of spider was higher in the plots of the bioinsecticide compared to that of the abamectin. Predatory insects found belonged to 14 species belonged to eight families dominated by species of Ophionea nigrofasciata, Verania discolor, and Paedorus fuscipe. The abundance of predatory insects in plots sprayed with the bioinsecticides was higher compared to that of the abamectin plot. The abundance and species diversity of predatory arthropod sprayed with bioinsecticide of $B$. bassiana, M. anisopliae, and C. militaris did not decrease, while the population of herbivore insect tended to decrease.
\end{abstract}

Keywords: Beauveria bassiana; Metarhizium anisopliae; Cordyceps militaris; neutral insect; parasitoid

\section{INTRODUCTION}

Rice cultivation in freshwater swamps of South Sumatra has specific characteristics making it different from rice cultivation in other ecosystems in Indonesia (Karenina et al. 2020). Rice cultivation is affected by climate conditions, especially rainfall and tidal flush (Herlinda et al. 2020). From November to April, freshwater swamp is generally inundated so that local farmers cultivate rice only in the period of May to September (Herlinda et al. 2018; Herlinda et al. 2019a). Due to difficulties in managing water, farmers grow rice once a year using the transplanting method. In maintaining their rice cultivations, the local farmers scarcely apply synthetic insecticide (Herlinda et al. 2019b).

The population of insect pests attacking freshwater swamp rice plants is increasing and starting to result in yield loss, especially rice bug (Leptocorixa acuta), while brown planthopper (Nilavarpata lugens) that has not appeared for a long time start attacking (Hanif et al. 2020). Pests that attack rice plants have been controlled using various entomopathogenic fungi including Beauveria bassiana $(\mathrm{Li}$ et al. 2012; Li et al. 2014; Lee et al. 2015), Metarizhium anisopliae (Girish and Balikai, 2015; Chinniah et al. 2016) and Cordyceps militaris (Prabawati et al. 2019). $C$. militaris is reported to produce beauvericin that is toxic to insects (Rachmawati et al. 2018) and B. bassiana has been reported to be effective against homopteran ( $\mathrm{Li}$ et al. 2012; Li et al. 2014; Lopez et al. 2014; Lee et al. 2015; Sumikarsih et al. 2019), coleopteran (Kavallieratos et al. 2015), hemipteran (Girish and Balikai 2015), and lepidopteran insects (Ayudya et al. 2019; Ma et al. 2019; Gustianingtyas et al. 2020). M. anisopliae has also been demonstrated to be effective against homopteran (Mweke et al. 2019), lepidopteran (Gustianingtyas et al. 2020), and coleopteran insects (Kavallieratos et al. 2015). $M$. 
anisopliae could be used in multiple roles, ranging from controlling insect pests and promoting plant growth (Liu et al. 2017).

Being effective against various orders of insects, including the coleopteran insects (Kavallieratos et al. 2015), the rice field ecosystem which is dominated by species of predatory insects, it is important to be very careful in the application of entomopathogenic fungi in ecosystem to avoid negative impact on non-target arthropods (Scorsetti et al. 2017). High species diversity and abundance of arthropod in freshwater swamp rice field (Herlinda et al. 2018) might be disturbed by the application of the entomopathogenic fungi. However, there have been some reports suggested that entomopathogenic fungi did not affect abundance and species diversity of arthropods (Prabawati et al. 2019; Hanif et al. 2020). For example, predatory insect in paddy field (Andrallus spinidens) was reported to be resistant to $B$. bassiana (Firouzbakht et al. 2015; Gholamzadeh-Chitgar et al. 2017; Scorsetti et al. 2017). Parasitoid tends to avoid host insect infected by entomopathogenic fungi (Emami et al. 2013). Coccinellidae, the family of generalist predatory insects, was reported to be resistant to M. anisopliae (Bayissa et al. 2016). This research aimed to analyze individual quantity of herbivore insects and predatory arthropod inhabiting freshwater swamp rice field treated with bioinsecticides containing Beauveria bassiana, Metarhizium anisopliae, and Cordyceps militaris and the abamectin.

\section{MATERIALS AND METHODS}

\section{Study area}

The research was conducted from April to August 2018 in the freshwater swamp rice field located in Village Pelabuhan Dalam, Sub District Pemulutan, District Ogan Ilir, and South Sumatra, Indonesia. The experiment was arranged in a Completely Randomized Block Design consisted of four plots of treatment. The first three plots were treated with bioinsecticide containing B. bassiana, $M$. anisopliae, and C. military, and the fourth plot was treated with the abamectin (the commercial insecticide) as control. The plot area was $120 \mathrm{~m}^{2}$ for treatment and each treatment was replicated five times. Distance between plots was 10 m.

\section{Land preparation, transplanting, and crop maintenance}

Land preparation was conducted using a moldboard plow and was continued by using harrow plow. Before being plowed, the land was cleared using a hoe and a long knife. The excessive water was pumped out until the soil was slightly watery, and the dung compost was added at a dosage of 1 ton $\mathrm{ha}^{-1}$. Rice seed used was certified purple labeled seed of Mekongga variety at a dosage of $50 \mathrm{~kg} \mathrm{ha}^{-1}$. Rice was cultivated using a transplanting system from which the seedlings were prepared in 34 x $26 \times 5 \mathrm{~cm}^{3}$ plastic trays filled with $3 \mathrm{~cm}$ high soil. The seeds were soaked in water for 24 hours before being planted in the prepared plastic trays. The soaked seeds were spread evenly in each tray at a dosage of $150 \mathrm{~g}$ per tray. The trays were then covered with thick plastic for seven days. The seven-day-old seedlings were then transferred to places receiving enough sunlight. Fourteen-day old seedlings were transplanted to all prepared plots at a density of 2 seedlings per hole in a $2: 1\left(12.5 \times 25 \times 50 \mathrm{~cm}^{3}\right)$ "jajar legowo" planting system (Figure 1).

Crop maintenance was conducted in the form of replanting, irrigating, weeding, and fertilizing. Replanting was conducted seven days after transplanting to replace the dead seedlings. Irrigating was conducted by making use of water flush from the river under high tide and pumping system. Weeding was conducted both at vegetative and generative stages using a sickle. Fertilizer used was shrimp shell extract compost prepared according to the method by Suwandi et al. (2012). The compost was applied every two weeks started from 14 days after planting until harvesting (84 days) at a dosage of $2 \mathrm{~L} \mathrm{ha}^{-1}$. The extract compost was a fermentation result of shrimp shell meal containing chitinolytic bacteria, cellulolytic bacteria, and sulfate diluter. Nitrogen fertilizer was applied 30 days after planting at a dosage of $100 \mathrm{~kg} \mathrm{ha}^{-1}$.

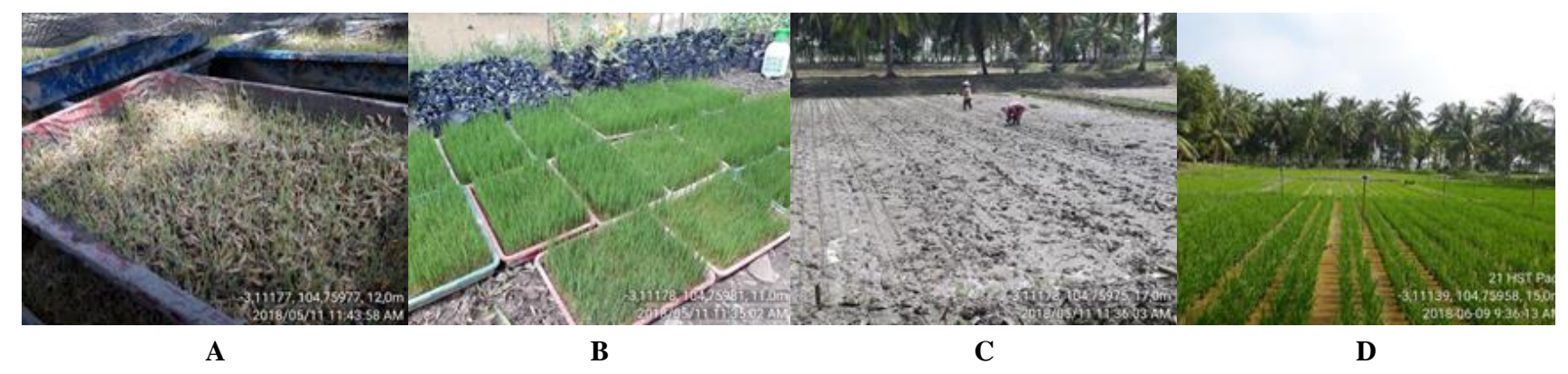

Figure 1. Two-day old rice seedling in a plastic tray (A), 7-day old seedlings (B), rice transplanting (D) rice planted in "jajar legowo" planting system (E) 


\section{Formulation and application of bioinsecticides}

All species of fungi have been explored from soil following the modified method of Kin et al. (2017). B. bassiana and $M$. anisopliae used in this research were explored from freshwater swamp soil of South Sumatra, while $C$. militaris was explored from the soil in Central Kalimantan, Indonesia. B. bassiana, M. anisopliae, and $C$. militaris were cultured in solid media of Sabouraud Dextrose Agar (SDA, Merck) made from 16.2 g SDA in $250 \mathrm{~mL}$ aquadest. The cultures were incubated for $10 \times 24$ hours. The 10 days old fungal solid cultures were then cultured in liquid media (Figure 2) of Sabouraud Dextrose Broth (SDB, Merck) made from $30 \mathrm{~g} \mathrm{SDB}$ in $1000 \mathrm{ml}$ aquadest and were incubated in a $120 \mathrm{rpm}$ shaker for 7 x 24 hours. The liquid culture of the entomopathogenic fungi was used to make bioinsecticide. Seven days after incubation, the density of fungal spores of the bioinsecticide was counted, the counting was stopped when the spore density reached $1 \times 10^{9}$ conidia $\mathrm{mL}^{-1}$. One liter of bioinsecticide was made by adding $400 \mathrm{~mL}$ shrimp shell meal extract compost as a carrier and active ingredient consisting of $600 \mathrm{~mL}$ liquid culture of entomopathogenic fungi and $10 \mathrm{~mL}$ vegetable oil. Compost extract used to make bioinsecticide was previously autoclaved under 1 atm for 2 hours.

The bioinsecticides were applied at a dosage of $2 \mathrm{~L} \mathrm{ha}^{-1}$ per application. The applications were conducted at 13, 27, $41,55,69$, and 83 days after transplanting (DAT). The bioinsecticide applications were conducted in the evening (at $5 \mathrm{pm}$ ) to avoid spores damaged by ultraviolet. The control plot was sprayed with abamectin at a dosage of 0.5 $\mathrm{L} \mathrm{ha}^{-1}$. The insecticide contained abamectin active ingredient and was sprayed at the same time as bioinsecticide applications. The control plot was $50 \mathrm{~m}$ away from treatment plots to avoid contamination in the treatment plots, and there was $10 \mathrm{~m}$ distance between bioinsecticide treatment plots. A day after application, arthropod samplings were carried out to collect arthropods inhabiting rice canopy.

\section{Arthropod sampling in rice canopy}

Sampling to collect arthropods inhabiting rice canopy was conducted using an entomological net $(75 \mathrm{~cm}$ length, $30 \mathrm{~cm}$ diameter, and $100 \mathrm{~cm}$ length of handle) (Lami et al. 2016; Ivantsova et al. 2017). Sampling was conducted in every treatment subplot and was repeated five times. Samplings were conducted at 14, 28, 42, 56, 70, and 84 DAT. Arthropod samplings were conducted in the morning, at 06.00-07.00 am. During sampling, the sweep net was swept $30 \mathrm{~cm}$ depth into rice canopy to collect representative samples.

Sampled arthropods were cleaned and placed in the labeled plastic bottles $(330 \mathrm{~mL})$ containing $100 \mathrm{~mL}$ absolute ethanol. The samples were brought into the Laboratory of Entomology, Department of Plant Pest and Disease, Faculty of Agriculture, Universitas Sriwijaya for identification. Spider identification was conducted using the reference of Barrion and Litsinger (1995), while for insect identification we used reference of Gullan and Cranston (2014) and Heinrichs et al. (2017).

\section{Data analysis}

Data of arthropods species were grouped based on their guild, comprised of herbivore insects, predators, parasitoids, and neutral insects, and was presented in the form of a graphic. The difference of individual quantity of the herbivore insects, spiders, and predatory insects amongst treatments was analyzed using Analysis of Variance (ANOVA). If there was a significant difference among treatments, the analysis was continued with Tukey's HSD (Honesty Significant Difference) test at 5\% degree of significance. Analyses data was conducted using Software of SAS University Edition 2.7 9.4 M5. Data of abundance were used to analyze species diversity by using the Shannon index (H'). Degree of diversity was counted using the Evenness index (J') derived from the Shannon function, and Berger-Parker dominance biodiversity indices. The coefficient of Sorensen was counted to measure the degree of similarity of the spider or predatory insect among treatments (Magurran 2004).

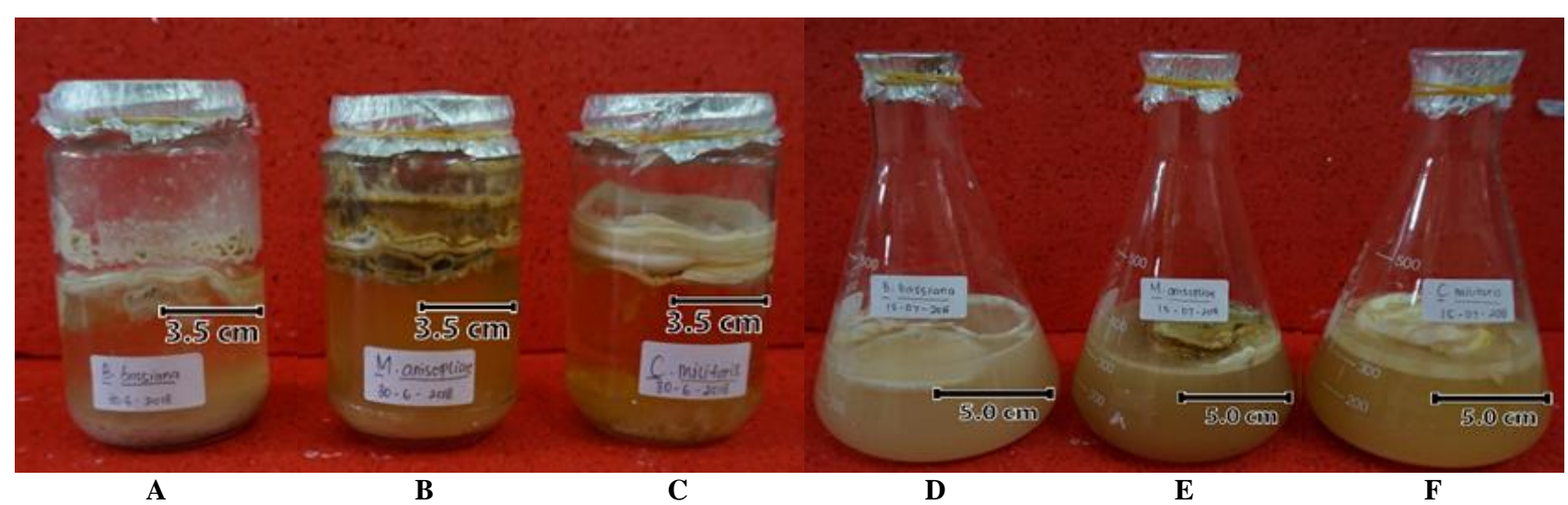

Figure 2. Cultures of Beauveria bassiana (A), Metarhizium anisopliae (B), and Cordyceps militaris (C) on SDB; liquid bioinsecticide of Beauveria bassiana (D), Metarhizium anisopliae (E), and Cordyceps militaris (F) 


\section{RESULTS AND DISCUSSION}

\section{Abundance of herbivore insects in one rice cropping season}

In one rice cropping season, it was found 22 species of herbivore insects belonged to 12 families. Dominant herbivore species were Nilaparvata lugens, Leptocorisa acuta, Acrida turrita, Valanga nigricornis, and Dicladispa armigera (Figure 3). The population of the herbivore was not significantly different among treatments, except for Family Cecidomyiidae (Table 1). Therefore, the capacity of bioinsecticide in suppressing the population of the herbivore insects has generally almost similar to the capacity of the abamectin.

During field observations, insect died due to infection by entomopathogenic fungi were documented and showed specific symptoms of each fungus. The larvae of $S$. litura found infected by $B$. bassiana in the rice field showed white mycelia covering its body, the dried, and not smelly (Figure 4). Larvae of S. litura infected by M. anisopliae showed symptoms of the dried body covered by greenish white mycelia and was not smelly, while larvae of S. litura infected by $C$. militaris showed similar symptoms to those of $B$. bassiana infection, larval body drying, shriveled, covered by white mycelia, and not smelly. Entomopathogenic fungi infected sampled insects were isolated and purified in the laboratory. Color, structure, and spore of the isolated fungi were as presented in Figure 5.

\section{Abundance of spider and predatory insect in one rice cropping season}

This research found 32 species of spiders belonged to eight families. The dominant species of them were Tetragnatha virescens, T. virescens, T. maxilosa, Argiope catenulata, and Oxyopes matiensis (Figure 6). The total abundance of spiders in the plot treated with the abamectin was significantly lower than that of plots treated with bioinsecticide (Table 2). The abundance of Bathyphantes sp. in abamectin plot decreased. The highest abundance of Araneus inustus was found in the plot treated with bioinsecticide $C$. militaris and was different from that of other treatments. The abundance of Tetragnathidae was significantly decreasing in the plot treated with insecticide was found to be lower compared to plots treated with bioinsecticide.

Predatory insects found in this research belonged to 14 species and eight families. The dominant species were Formicomus sp., Ophionea nigrofasciata, Verania discolor, Verania lineata, Menochilus sexmaculatus, Micrapis inop, Paedorus fuscipe, Cyrtorhinus lividipennis, and Orthotylus sp. (Figure 7). The abundance of predatory insects was not significantly different among treatments (Table 3).

\section{Characteristic of spider and predatory insect community in one rice cropping season}

The number of spiders increased with increasing rice age (Table 4). The highest number of spiders occurred when the rice was at a mature grain ripening stage (84 DAT). The abundance of spider in the plot treated with abamectin tend to be lower compared to that of plots treated with the bioinsecticides. The total number of spiders in one rice cropping season was higher in the plots treated with the bioinsecticide than that in the plot treated with the abamectin. The species diversity of spiders was also higher in the plots treated with entomopathogenic fungal bioinsecticide compared to that in the abamectin plot. The high species diversity in plots treated with entomopathogenic fungal bioinsecticide was also followed by the high species evenness and low species dominance.

Number of predatory insects decreased with increasing stages of rice, but at approaching harvest (84 DAT), the number of predatory insects drastically decreased (Table 5). The highest abundance of predatory insects occurred at the milk grain ripening stage (70 DAT). The phenomenon of abundance fluctuation of predatory insects was slightly different from that of spider, which its peak occurred at a mature grain ripening stage (84 DAT). The abundance of the predatory insects in plots treated with abamectin was generally lower than that of plots treated with the entomopathogenic fungal bioinsecticide. Total abundance of predatory insects in one rice cropping season of plots sprayed with entomopathogenic fungal bioinsecticide was higher compared to that of abamectin plot. However, species diversity, evenness, and species dominance tend to be similar among treatments.

Spider community in plot sprayed with the bioinsecticide of $B$. bassiana tends to be more similar to that of plots sprayed with bioinsecticide (M. anisopliae and $C$. militaris) than that of abamectin plot. The total of one rice cropping season, spider community in plot sprayed with bioinsecticide $B$. bassiana was more similar to that of plot of $C$. militaris (0.77), followed by plot M. anisopliae (0.76), and least similar to that of the abamectin plot $(0.49)$ (Table 6).

Predatory insect community in plot sprayed with bioinsecticide $B$. bassiana tent to be more similar to that of plots sprayed with bioinsecticide $M$. anisopliae and $C$. militaris than that of the abamectin plot (Table 7). The total of one rice cropping season, predatory insect community in plots sprayed with bioinsecticide $B$. bassiana was more similar to that of plot M. anisopliae (0.91), followed by plot of $C$. militaris (0.85), and least similar to that of insecticide plot (0.66). 


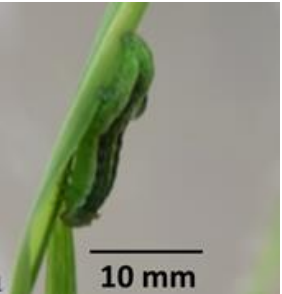

A

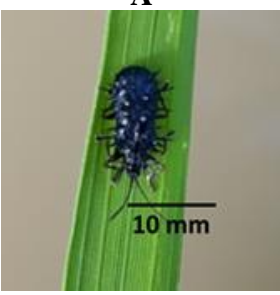

$\mathbf{F}$

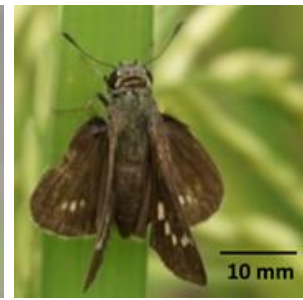

B

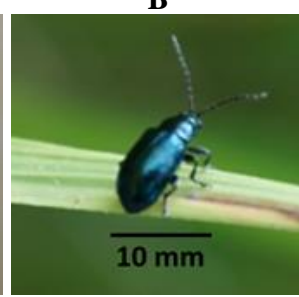

G
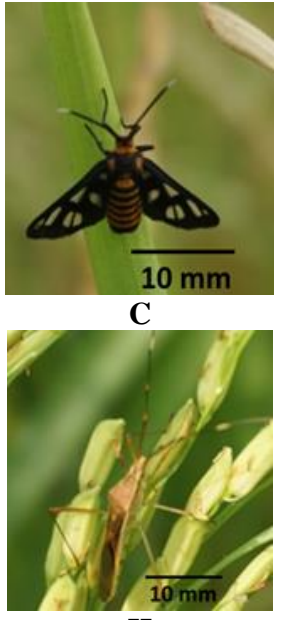

$\mathbf{H}$

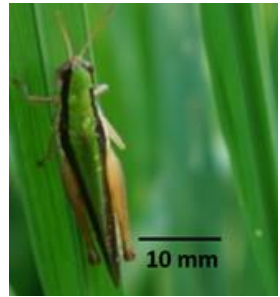

D

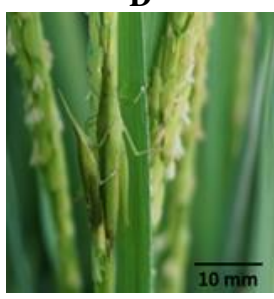

I
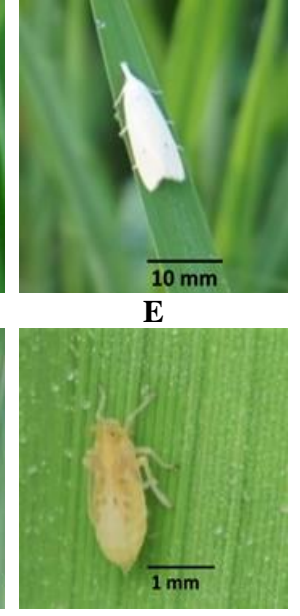

$\mathbf{J}$

Figure 3. Herbivore insects found in rice canopy: Spodoptera sp. (A), Pelopidas sp. (B), Amata nigriceps (C), Oxya chinensis (D), Scirpophaga sp. (E), Dicladispa armigera (F), Chrysolina coerulans $(\mathrm{G})$, Leptocorisa acuta $(\mathrm{H})$, Acrida turita $(\mathrm{I})$, Nilaparvata lugens $(\mathrm{J})$

Table 1. Population of herbivore insects in rice canopy sprayed with bioinsecticides (B. bassiana, M. anisopliae, C. militaris) and abamectin

\begin{tabular}{|c|c|c|c|c|c|c|c|}
\hline \multirow{2}{*}{ Ordo / family/ species } & \multicolumn{4}{|c|}{ Mean of herbivore abundance (individuals/nets) } & \multirow{2}{*}{ F-value } & \multirow{2}{*}{$\begin{array}{r}\text { P-value } \\
(0.05)\end{array}$} & \multirow{2}{*}{$\begin{array}{c}\text { Tukey's HSD } \\
\text { test }\end{array}$} \\
\hline & B. bassiana & M. anisopliae & C. militaris & Abamectin & & & \\
\hline COLEOPTERA & 0.2 & 0.13 & 0.17 & 0.23 & 0.26 & 0.85 & \\
\hline Chrysomelidae & 0.2 & 0.13 & 0.17 & 0.23 & 0.26 & 0.85 & \\
\hline Chrysolina coerulans & 0.07 & 0 & 0.07 & 0.2 & 2.11 & 0.15 & \\
\hline Dicladispa armigera & 0.13 & 0.13 & 0.1 & 0.03 & 0.53 & 0.67 & \\
\hline DIPTERA & $0.4^{\mathrm{b}}$ & $0.03^{\mathrm{ab}}$ & $0.07^{\mathrm{ab}}$ & $0.00^{\mathrm{a}}$ & $4.40 *$ & 0.03 & 0.20 \\
\hline Cecidomyiidae & $0.4^{\mathrm{b}}$ & $0.03^{\mathrm{ab}}$ & $0.07^{\mathrm{ab}}$ & $0.00^{\mathrm{a}}$ & $4.40^{*}$ & 0.03 & 0.20 \\
\hline Cecidomyiidae sp. & 0.33 & 0 & 0 & 0 & 2.55 & 0.1 & \\
\hline HEMIPTERA & 1.67 & 1.1 & 1.7 & 0.97 & 2.42 & 0.12 & \\
\hline Alydidae & 0.57 & 0.4 & 0.73 & 0.5 & 2.02 & 0.17 & \\
\hline Leptocorisa acuta & 0.57 & 0.4 & 0.73 & 0.5 & 2.02 & 0.17 & \\
\hline Cicadellidae & 0.17 & 0.1 & 0 & 0.1 & 0.42 & 0.74 & \\
\hline Nephotettix cincticeps & 0 & 0 & 0 & 0.03 & 1.00 & 0.43 & \\
\hline Nephotettix virescen & 0 & 0.1 & 0 & 0.07 & 1.04 & 0.41 & \\
\hline Recilia dorsalis & 0.17 & 0 & 0 & 0 & 1.00 & 0.43 & \\
\hline Delphacidae & 0.93 & 0.6 & 0.97 & 0.37 & 2.59 & 0.1 & \\
\hline Sogatella furcifera & 0.17 & 0.07 & 0.07 & 0.1 & 0.50 & 0.69 & \\
\hline LEPIDOPTERA & 0.37 & 0.3 & 0.5 & 0.17 & 2.61 & 0.1 & \\
\hline Pyralidae & 0.33 & 0.23 & 0.33 & 0.17 & 0.99 & 0.43 & \\
\hline Cnaplocrosis medinalis & 0 & 0 & 0 & 0.03 & 1.00 & 0.43 & \\
\hline Scirpophaga incertulas & 0.17 & 0.13 & 0.17 & 0.07 & 1.31 & 0.32 & \\
\hline Scirpophaga sp. & 0.17 & 0.1 & 0.17 & 0.07 & 0.66 & 0.59 & \\
\hline Erebidae & 0 & 0 & 0.07 & 0 & 1.00 & 0.43 & \\
\hline Amata nigriceps & 0 & 0 & 0.07 & 0 & 1.00 & 0.43 & \\
\hline Hesperiidae & 0 & 0 & 0.03 & 0 & 1.00 & 0.43 & \\
\hline Pelopidas mathias & 0 & 0 & 0.03 & 0 & 1.00 & 0.43 & \\
\hline Noctudae & 0.03 & 0.07 & 0.07 & 0 & 0.47 & 0.71 & \\
\hline Spodoptera sp. & 0.03 & 0.07 & 0.07 & 0 & 0.47 & 0.71 & \\
\hline ORTHOPTERA & 0.63 & 0.83 & 0.67 & 0.8 & 0.58 & 0.64 & \\
\hline Acrididae & 0.63 & 0.83 & 0.67 & 0.77 & 0.48 & 0.7 & \\
\hline Acrida turrita & 0.2 & 0.17 & 0.1 & 0.4 & 2.68 & 0.09 & \\
\hline Gesonula mundata & 0.03 & 0.1 & 0.03 & 0.1 & 0.35 & 0.79 & \\
\hline Oxya chinensis & 0.07 & 0.1 & 0.1 & 0.1 & 0.07 & 0.97 & \\
\hline Atractomorpha crenulata & 0 & 0 & 0 & 0.03 & 1.00 & 0.43 & \\
\hline THYSANOPTERA & 0.1 & 0.1 & 0.1 & 0.07 & 0.11 & 0.95 & \\
\hline Thripidae & 0.1 & 0.1 & 0.1 & 0.07 & 0.11 & 0.95 & \\
\hline Liothrips sp. & 0.1 & 0.1 & 0.1 & 0.07 & 0.11 & 0.95 & \\
\hline Total & 3.37 & 2.5 & 3.2 & 2.23 & 2.77 & 0.09 & \\
\hline
\end{tabular}

Note: *: significantly different; values within a row followed by the same letters were not significantly different at $\mathrm{P}<0.05$ according to Tukey's HSD test 


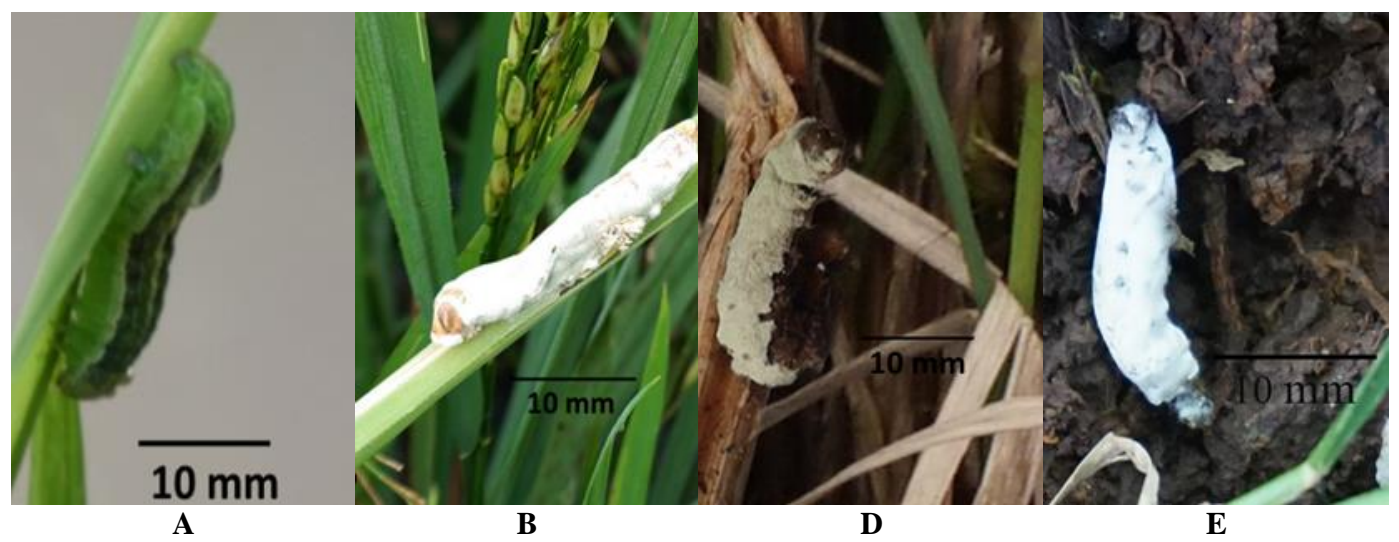

Figure 4. Herbivore insects infected by the entomopathogenic fungal of bioinsecticide in rice field: healthy larvae of Spodoptera sp. (A), infected by B. bassiana (B), infected by M. anisopliae (C), and infected by C. militaris (D)

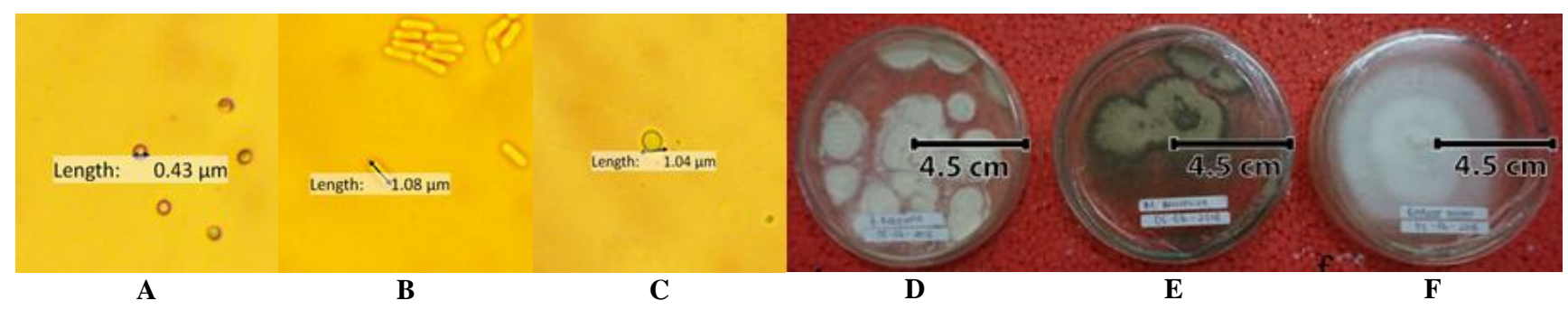

Figure 5. Spores of Beauveria bassiana (A), Metarhizium anisopliae (B), and Cordyceps militaris (C); colonies of Beauveria bassiana (d), Metarhizium anisopliae (E), and Cordyceps militaris (F)
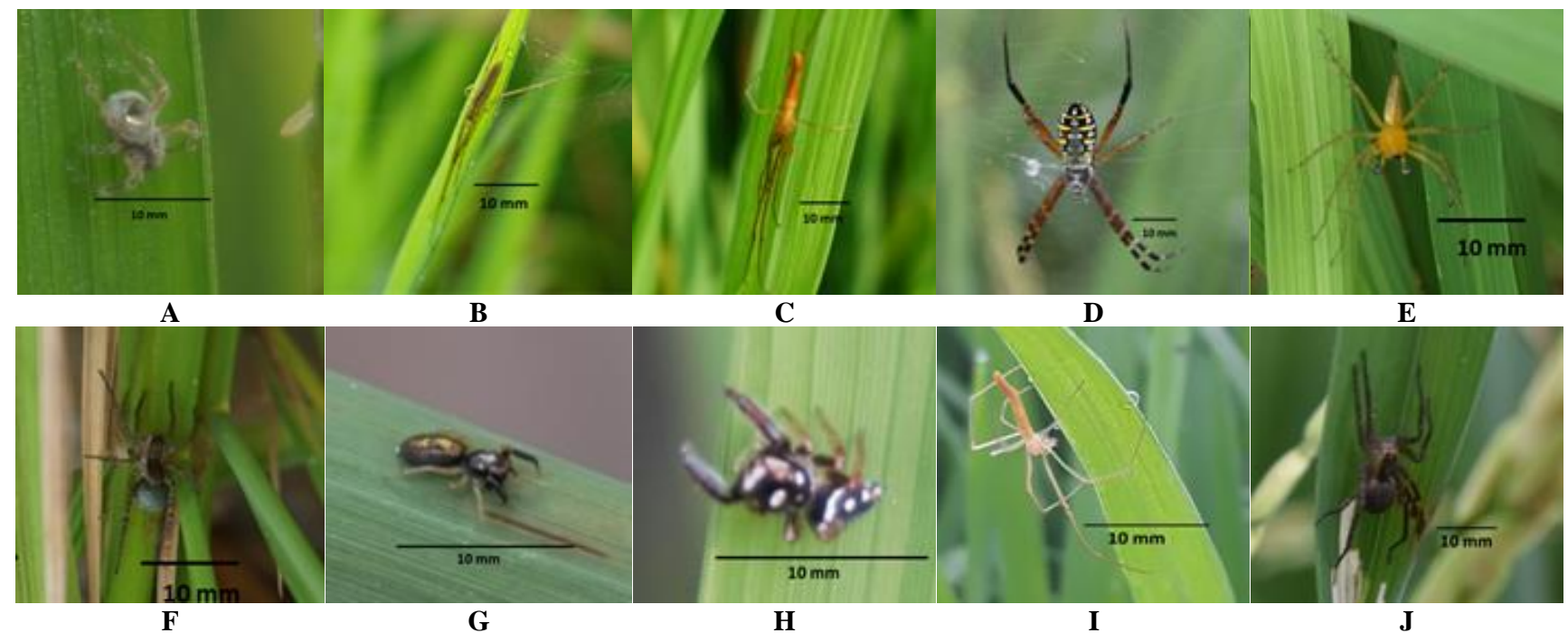

B

C

D

E
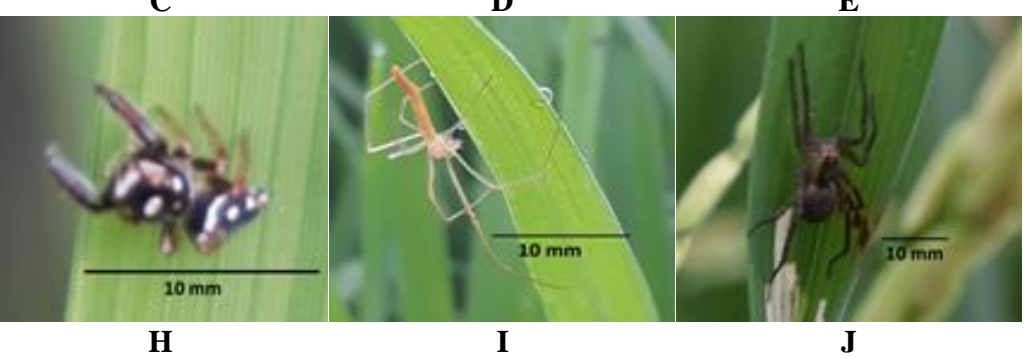

Figure 6. Spiders found in rice canopy: Linyphiidae (A), Tetragnatha virescens (B), Tetragnatha maxilosa (C), Argiope catenulate (D), Oxyopes matiensis (E), Lycosidae (F), Salticidae sp. A (G), Salticidae sp. B (H), Oxyopes javanus (I), Pardosa sp. (J) 


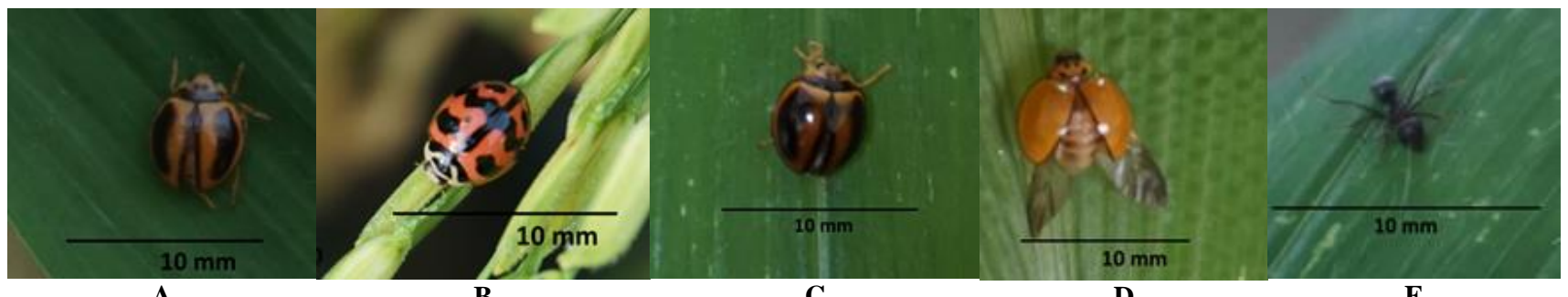

A

B

C

E

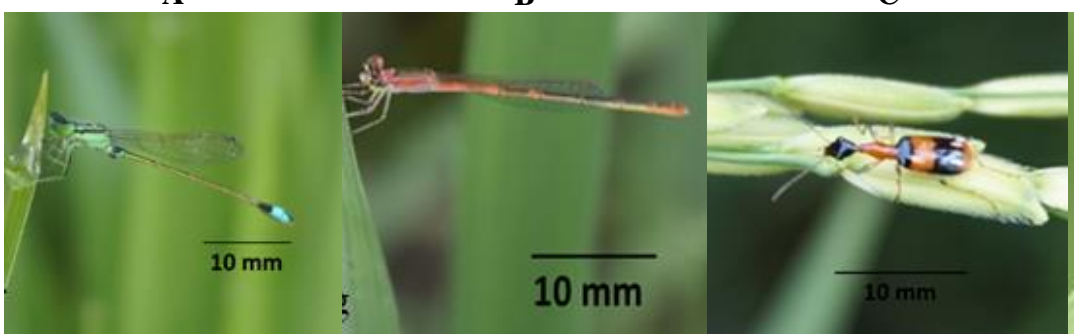

$\mathbf{F}$

G
D

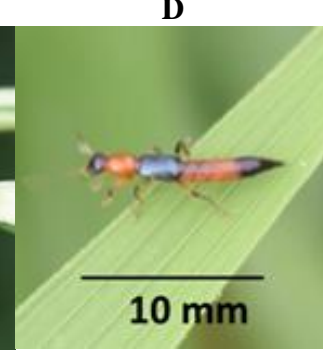

I

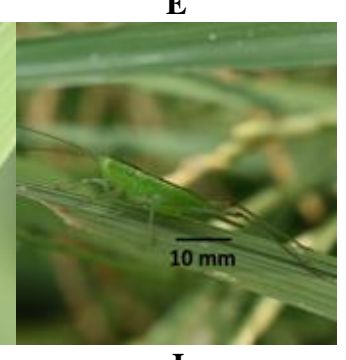

J

Figure 7. Predatory insect in rice field: Verania lineata (A), Menochilus sexmaculatus (B), Micrapis inops (C), Formica sp. (D), Odontoponera transversa (E), Argia sp. (F), Agriocnemis sp. (G), Ophionea nigrofasciata (H), Paederus fuscipes (I), and Conocephalus longipennis (J)
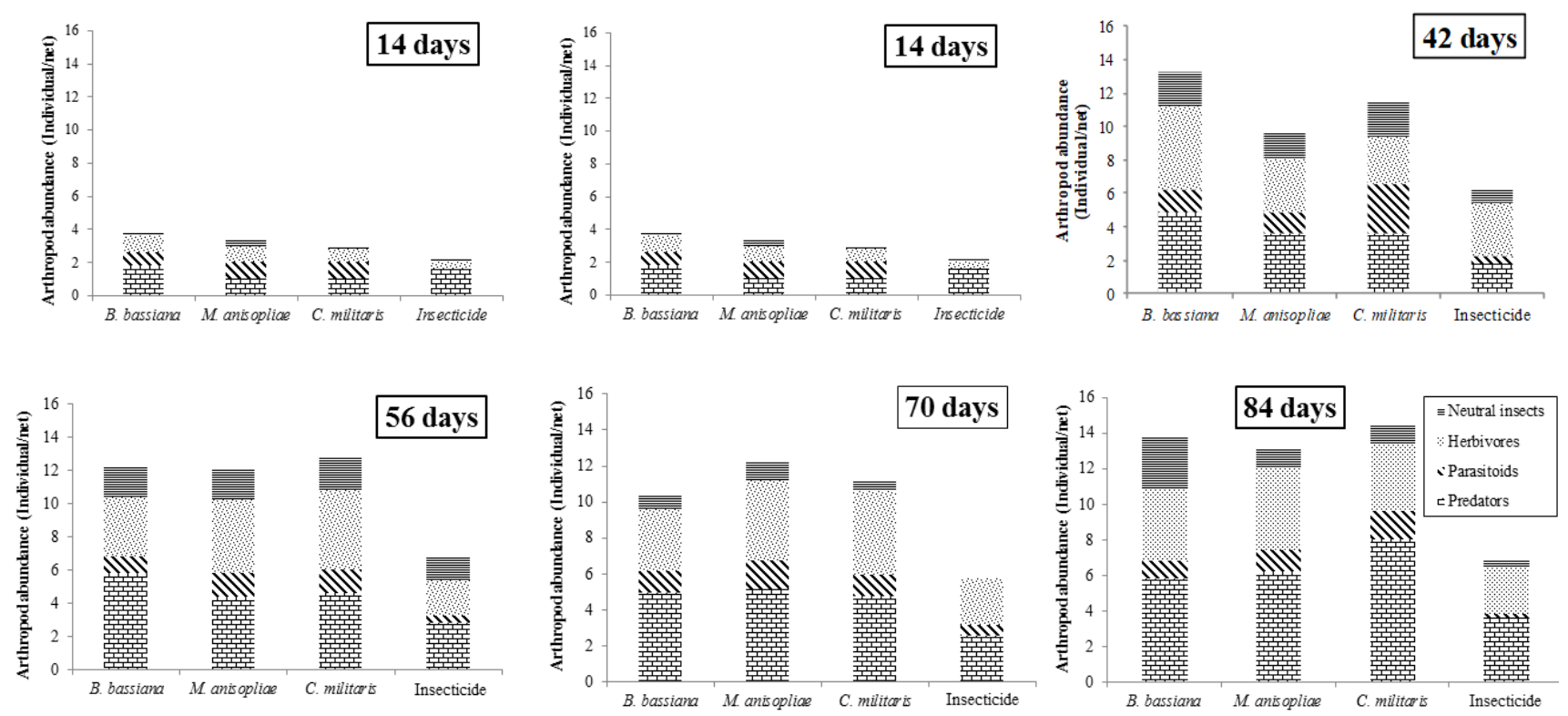

Figure 8. Arthropod abundance on rice field treated with bioinsecticides and abamectin (insecticide) 
Table 2. The abundance of spider inhabiting rice canopy sprayed with bioinsecticides (B.bassiana, M. anisopliae, and C. militaris) and abamectin

\begin{tabular}{|c|c|c|c|c|c|c|c|}
\hline \multirow{2}{*}{ Ordo / family/ species } & \multicolumn{4}{|c|}{ Mean of spider abundance (individuals/nets) } & \multirow{2}{*}{ F-value } & \multirow{2}{*}{$\begin{array}{r}\text { P-value } \\
(0.05)\end{array}$} & \multirow{2}{*}{$\begin{array}{c}\text { Tukey's } \\
\text { HSD tes }\end{array}$} \\
\hline & B. bassiana & M. anisopliae & C. militaris & Abamectin & & & \\
\hline ARACHINIDA & & & & & & & \\
\hline Araneidae & 0.03 & 0.07 & 0.27 & 0.13 & 2.02 & 0.17 & \\
\hline Araneus inustus & $0.00^{\mathrm{a}}$ & $0.03^{\mathrm{ab}}$ & $0.2^{\mathrm{b}}$ & $0.03^{\mathrm{ab}}$ & $4.82 *$ & 0.02 & 0.11 \\
\hline Araneidae sp. & 0.03 & 0.03 & 0.07 & 0.07 & 0.35 & 0.79 & \\
\hline Gea subarmata & 0.00 & 0.00 & 0.00 & 0.03 & 1.00 & 0.43 & \\
\hline Linyphiidae & 0.47 & 0.30 & 0.20 & 0.10 & 2.76 & 0.09 & \\
\hline Bathyphantes tagalogensis & 0.00 & 0.00 & 0.07 & 0.00 & 2.67 & 0.10 & \\
\hline Bathyphantes sp. A & 0.07 & 0.00 & 0.00 & 0.07 & 0.89 & 0.48 & \\
\hline Bathyphantes sp. B & $0.13^{\mathrm{ab}}$ & $0.2^{\mathrm{b}}$ & $0.07^{\mathrm{ab}}$ & $0^{\mathrm{a}}$ & $3.74 *$ & 0.04 & 0.12 \\
\hline Atypena adelinae & 0.03 & 0.03 & 0.03 & 0.03 & 0.00 & 1.00 & \\
\hline Erigone bifurca & 0.03 & 0.00 & 0.00 & 0.00 & 1.00 & 0.43 & \\
\hline Linyphiidae sp. A & 0.20 & 0.03 & 0.03 & 0.00 & 2.46 & 0.11 & \\
\hline Atypena formosana & 0.00 & 0.03 & 0.00 & 0.00 & 0.98 & 0.44 & \\
\hline Lycosidae & 0.10 & 0.13 & 0.37 & 0.10 & 1.90 & 0.18 & \\
\hline Arctosa sp. & 0.00 & 0.03 & 0.03 & 0.00 & 0.60 & 0.63 & \\
\hline Pardosa birmanica & 0.03 & 0.00 & 0.00 & 0.00 & 1.00 & 0.43 & \\
\hline Pardosa pseudoannulata & 0.03 & 0.00 & 0.27 & 0.07 & 2.10 & 0.15 & \\
\hline Pardosa apostoli & 0.00 & 0.03 & 0.00 & 0.00 & 1.00 & 0.43 & \\
\hline Pardosa pullata & 0.03 & 0.03 & 0.03 & 0.00 & 0.37 & 0.77 & \\
\hline Hogna rizali & 0.00 & 0.00 & 0.03 & 0.00 & 1.00 & 0.43 & \\
\hline Pirata luzonensis & 0.00 & 0.03 & 0.00 & 0.03 & 0.62 & 0.62 & \\
\hline Oxyopidae & 0.03 & 0.03 & 0.10 & 0.03 & 0.51 & 0.68 & \\
\hline Oxyopes javanus & 0.00 & 0.03 & 0.07 & 0.03 & 0.76 & 0.54 & \\
\hline Oxyopes matiensis & 0.00 & 0.00 & 0.03 & 0.00 & 1.00 & 0.43 & \\
\hline Oxyopes pingasus & 0.03 & 0.00 & 0.00 & 0.00 & 1.00 & 0.43 & \\
\hline Salticidae & 0.07 & 0.07 & 0.07 & 0.07 & 0.00 & 1.00 & \\
\hline Salticidae sp. A & 0.03 & 0.00 & 0.03 & 0.03 & 0.38 & 0.77 & \\
\hline Salticidae sp. B & 0.03 & 0.07 & 0.03 & 0.03 & 0.37 & 0.77 & \\
\hline Theridiidae & 0.07 & 0.03 & 0.03 & 0.00 & 0.62 & 0.62 & \\
\hline Theridiidae sp. & 0.07 & 0.03 & 0.03 & 0.00 & 0.62 & 0.62 & \\
\hline Tetragnathidae & $1.33^{\mathrm{b}}$ & $1.2^{\mathrm{ab}}$ & $1.2^{\mathrm{ab}}$ & $0.63^{\mathrm{a}}$ & $4.16^{*}$ & 0.03 & 0.28 \\
\hline Tetragnatha javana & 0.33 & 0.40 & 0.43 & 0.20 & 2.40 & 0.12 & \\
\hline Tetragnatha maxillosa & 0.07 & 0.07 & 0.03 & 0.03 & 0.24 & 0.87 & \\
\hline Tetragnatha montana & 0.07 & 0.00 & 0.03 & 0.03 & 0.37 & 0.77 & \\
\hline Tetragnatha virescens & 0.47 & 0.33 & 0.37 & 0.23 & 0.76 & 0.54 & \\
\hline Tetragnatha nitens & 0.00 & 0.03 & 0.03 & 0.03 & 0.38 & 0.77 & \\
\hline Tetragnatha okumae & 0.33 & 0.13 & 0.10 & 0.10 & 1.88 & 0.19 & \\
\hline Tetragnatha mandibulata & 0.03 & 0.07 & 0.10 & 0.00 & 0.84 & 0.50 & \\
\hline Tetragnatha vermiformis & 0.00 & 0.10 & 0.07 & 0.00 & 1.27 & 0.33 & \\
\hline Tetragnatha iwahigensis & 0.03 & 0.07 & 0.07 & 0.00 & 0.76 & 0.54 & \\
\hline Theridiosomatidae & 0.00 & 0.00 & 0.07 & 0.00 & 1.00 & 0.43 & \\
\hline Wendilgarda $\mathrm{sp}$ & 0.00 & 0.00 & 0.07 & 0.00 & 1.00 & 0.43 & \\
\hline Total Abundance (N) & $2.1^{\mathrm{b}}$ & $1.83^{\mathrm{ab}}$ & $2.3^{\mathrm{b}}$ & $1.07^{\mathrm{a}}$ & $7.29 *$ & 0.00 & 0.30 \\
\hline
\end{tabular}

Note: *: significantly different; values within a row followed by the same letters were not significantly different at $\mathrm{P}<0.05$ according to Tukey's HSD test

The abundance of associated arthropod with rice in one cropping season

The abundance of associated arthropods tends to increase with increasing rice growth stage (Figure 8). In all observations, the abundance of predatory insect was found to be higher compared to the abundance of other guilds (neutral insect, herbivore, and parasitoid). The abundance of predator was generally higher in plots sprayed entomopathogenic fungal bioinsecticide compared to that of abamectin plot. The abundance of all guilds of arthropod in the plot of abamectin was always lower compared to that of bioinsecticide plots. When rice was 70 days old, the abundance of herbivore reached its peak, then decreased at a mature grain stage. The abundance of predators reached its peak when rice was 84 days old. 
Table 3. The abundance of predatory insect in rice field sprayed with bioinsecticides (B. bassiana, M. anisopliae, and C. militaris) and abamectin

\begin{tabular}{|c|c|c|c|c|c|c|}
\hline \multirow{2}{*}{ Ordo / family/ species } & \multicolumn{4}{|c|}{ Mean of predatory insect abundance (individuals/nets) } & \multirow{2}{*}{$\begin{array}{r}\text { F value } \\
0.05\end{array}$} & \multirow{2}{*}{$\begin{array}{l}\text { P value } \\
(0.05)\end{array}$} \\
\hline & B. bassiana & M. anisopliae & C. militaris & Abamectin & & \\
\hline COLEOPTERA & 0.47 & 0.63 & 0.40 & 0.63 & 0.64 & 0.60 \\
\hline Anthicidae & 0.07 & 0.07 & 0.07 & 0.00 & 0.86 & 0.49 \\
\hline Formicomus sp. & 0.07 & 0.07 & 0.07 & 0.00 & 0.86 & 0.49 \\
\hline Carabidae & 0.10 & 0.17 & 0.17 & 0.07 & 1.07 & 0.40 \\
\hline Ophionea nigrofasciata & 0.10 & 0.17 & 0.17 & 0.07 & 1.07 & 0.40 \\
\hline Coccinellidae & 0.67 & 0.57 & 0.57 & 0.40 & 1.41 & 0.29 \\
\hline Verania discolor & 0.03 & 0.07 & 0.03 & 0.10 & 0.19 & 0.90 \\
\hline Verania lineata & 0.00 & 0.00 & 0.00 & 0.07 & 1.00 & 0.44 \\
\hline Menochilus sexmaculatus & 0.13 & 0.04 & 0.07 & 0.07 & 0.24 & 0.86 \\
\hline Micraspis inops & 0.50 & 0.47 & 0.47 & 0.17 & 3.14 & 0.07 \\
\hline Staphylidae & 0.27 & 0.30 & 0.33 & 0.27 & 0.36 & 0.78 \\
\hline Paederus fuscipes & 0.27 & 0.30 & 0.33 & 0.27 & 0.36 & 0.78 \\
\hline HEMIPTERA & 0.13 & 0.10 & 0.00 & 0.03 & 1.49 & 0.27 \\
\hline Miridae & 0.13 & 0.10 & 0.00 & 0.03 & 1.49 & 0.27 \\
\hline Cyrtorhinus lividipennis & 0.13 & 0.03 & 0.00 & 0.00 & 2.81 & 0.09 \\
\hline Orthotylus sp. & 0.00 & 0.07 & 0.00 & 0.03 & 0.74 & 0.58 \\
\hline HYMENOPTERA & 0.30 & 0.30 & 0.20 & 0.10 & 0.87 & 0.48 \\
\hline Formicidae & 0.30 & 0.30 & 0.20 & 0.00 & 0.87 & 0.48 \\
\hline Formica sp. & 0.07 & 0.13 & 0.03 & 0.00 & 0.61 & 0.66 \\
\hline Odontoponera transversa & 0.23 & 0.17 & 0.17 & 0.10 & 0.27 & 0.85 \\
\hline ODONATA & 0.33 & 0.20 & 0.20 & 0.20 & 0.34 & 0.80 \\
\hline Coenagrionidae & 0.33 & 0.20 & 0.20 & 0.20 & 0.34 & 0.80 \\
\hline Pyrrhosoma sp. & 0.20 & 0.07 & 0.10 & 0.10 & 1.00 & 0.43 \\
\hline Agriocnemis pygmaea & 0.20 & 0.07 & 0.10 & 0.10 & 0.10 & 0.96 \\
\hline ORTHOPTERA & 0.33 & 0.27 & 0.27 & 0.17 & 0.56 & 0.65 \\
\hline Tettigoniidae & 0.33 & 0.27 & 0.27 & 0.17 & 0.56 & 0.65 \\
\hline Conocephalus longipennis & 0.33 & 0.27 & 0.27 & 0.17 & 0.56 & 0.65 \\
\hline Total abundance (N) & 2.20 & 1.97 & 1.80 & 1.23 & 1.25 & 0.34 \\
\hline
\end{tabular}

Note: values within a row followed by the same letters were not significantly different at $\mathrm{P}<0.05$ according to Tukey's HSD test

\section{Discussion}

From this study, the population of herbivore insects in plots sprayed with the entomopathogenic fungal bioinsecticides was not significantly different from the population of the herbivore in the abamectin plot. This was because the entomopathogenic fungi applied in this research was effective and had capacity equal to the abamectin in reducing the population of herbivore insects. $B$. bassiana was proved to be effective in killing pest insects of rice, such as brown planthopper (Lee et al. 2015) and rice bug (Girish and Balikai 2015). In this research, $S$. litura found was infected by $B$. bassiana, M. anisopliae, and $C$. militaris. Gustianingtyas et al. (2020) also reported that $S$. litura subjected to infection by $M$. anisopliae. $C$. militaris could suppress the population of lepidopteran (Shrestha et al. 2016) and coleopteran pest insects (Kryukov et al. 2014).

Based on this study, symptoms developed on $S$. litura larvae infected by $B$. bassiana in the rice field were similar to the symptoms reported by Gustianingtyas et al. (2019) that host insect infected by $B$. bassiana was covered by white mycelia and its body was shriveled. Morphological characteristics of $B$. bassiana colony were in accordance with the result of isolation in the laboratory, white mycelia with hyaline 1-celled cylindrical and septate conidia (Safitri et al. 2018). M. anisopliae infecting S. litura in this research showed symptom as reported by Humber (2012) that the integument of infected insect turned to white to dark green, green to yellow conidia, 1-celled and cylindrical conidia, and septate hypha. Larvae of $S$. litura infected by $C$. militaris in the rice field showed symptoms similar to those of $B$. bassiana infection, and in accordance to symptoms characteristics reported by Kryukov et al. (2014) that infected insect was white in color with fruiting bodies appear from the insect, the colony was yellowishwhite in color, and conidia were globular in shape (Zheng et al. 2011).

In this research, the abundance of hunting spiders, such as species of Lycosidae did not decrease after being sprayed with the entomopathogenic fungal bioinsecticides well as after being sprayed with abamectin. The abundance of a web spider, such as Bathyphantes, A. inustus, and Family of Tetragnathidae, decreased after application of the abamectin, while application of the bioinsecticide could only decrease the population of $A$. inustus. Therefore, the entomopathogenic fungal bioinsecticides were relatively safer than the abamectin. Furthermore, spiders generally prey on healthy herbivore insects, while the herbivore insects infected by entomopathogen or the unhealthy ones would not be preyed (Chaubey and Yadav 2017). Web spider abundance decreased after the application of the abamectin and the bioinsecticides because the spiders were moving less in rice canopy, making the insecticide as well as the bioinsecticide easy to reach the spider body. Therefore, it would better to stop the application of bioinsecticide when the abundance of web spiders is high. 
Table 4. Characteristic of spider community in rice canopy sprayed with bioinsecticides (B. bassiana, M. anisopliae, and C. militaris) and abamectin

\begin{tabular}{|c|c|c|c|c|}
\hline Characteristic of spider community & B. bassiana & M. anisopliae & C. militaris & Abamectin \\
\hline \multicolumn{5}{|l|}{14 days } \\
\hline Abundance (individual/hill) & 0.80 & 0.40 & 0.80 & 0.80 \\
\hline Biodiversity index (H') & 1.03 & 0.69 & 1.38 & 1.38 \\
\hline Dominance index (D) & 0.50 & 0.50 & 0.25 & 0.25 \\
\hline Evenness index (E) & 0.94 & 1.00 & 1.00 & 1.00 \\
\hline \multicolumn{5}{|l|}{28 days } \\
\hline Abundance (individual/hill) & 1.00 & 1.20 & 1.20 & 0.40 \\
\hline Biodiversity index (H') & 1.33 & 1.24 & 1.79 & 0.69 \\
\hline Dominance index (D) & 0.40 & 0.50 & 0.16 & 0.50 \\
\hline Evenness index (E) & 0.96 & 0.89 & 1.00 & 1.00 \\
\hline \multicolumn{5}{|l|}{42 days } \\
\hline Abundance (individual/hill) & 2.2 & 1.80 & 2.00 & 0.80 \\
\hline Biodiversity index (H') & 1.03 & 1.67 & 1.74 & 1.03 \\
\hline Dominance index (D) & 0.45 & 0.33 & 0.40 & 0.50 \\
\hline Evenness index (E) & 0.94 & 0.93 & 0.89 & 0.94 \\
\hline \multicolumn{5}{|l|}{56 days } \\
\hline Abundance (individual/hill) & 3.00 & 1.80 & 2.20 & 1.00 \\
\hline Biodiversity index (H') & 1.70 & 1.30 & 1.12 & 1.33 \\
\hline Dominance index (D) & 0.33 & 0.55 & 0.54 & 0.40 \\
\hline Evenness index (E) & 0.87 & 0.80 & 0.80 & 0.96 \\
\hline \multicolumn{5}{|l|}{70 days } \\
\hline Abundance (individual/hill) & 2.40 & 2.40 & 2.60 & 1.00 \\
\hline Biodiversity index (H') & 1.97 & 1.81 & 2.35 & 1.79 \\
\hline Dominance index (D) & 0.25 & 0.41 & 0.15 & 0.16 \\
\hline Evenness index (E) & 0.95 & 0.87 & 0.98 & 1.00 \\
\hline \multicolumn{5}{|l|}{84 days } \\
\hline Abundance (individual/hill) & 3.20 & 3.40 & 5.00 & 2.20 \\
\hline Biodiversity index (H') & 1.53 & 1.39 & 2.07 & 1.66 \\
\hline Dominance index (D) & 0.56 & 0.58 & 0.40 & 0.45 \\
\hline Evenness index (E) & 0.73 & 0.71 & 0.80 & 0.85 \\
\hline \multicolumn{5}{|l|}{ TOTAL } \\
\hline Abundance (individual/hill) & 12.6 & 11 & 13.8 & 6.2 \\
\hline Biodiversity index (H') & 2.48 & 2.59 & 2.75 & 2.45 \\
\hline Dominance index (D) & 0.22 & 0.21 & 0.18 & 0.22 \\
\hline Evenness index (E) & 0.82 & 0.83 & 0.85 & 0.88 \\
\hline
\end{tabular}

The abundance of spiders increased, followed by the increase of rice stage, and the highest abundance occurred just before harvesting. The abundance of spiders continued to high until harvesting because spider likes complex habitat (Amzah et al. 2018) and inhabited by various insect species. Spider is also a generalist predator, prey on various insect species, include neutral insects, which are generally abundant before harvesting (Karenina et al. 2019). The species diversity of spiders in this research was also higher in plots sprayed with the entomopathogenic fungal bioinsecticide compared to that of the abamectin plot. The higher abundance and species diversity of spiders indicated that the entomopathogenic fungal bioinsecticide was not dangerous to their life. Many reports showed that entomopathogenic fungi did not kill spiders, especially hunting spiders (Prabawati et al. 2019; Hanif et al. 2020).

The abundance of predatory insects did not decrease after the application of the entomopathogenic fungal bioinsecticide or abamectin. The predatory insect has high mobility which differs them from web spiders so that predatory insect could escape from being exposed to bioinsecticide and abamectin. Furthermore, there is evidence that the avoidance behavior in predatory insects from B. bassiana-infected insect preys (Seiedy et al. 2015). Therefore, the application of entomopathogenic fungi was relatively safe for predatory insects.

The abundance of the predatory insect was increasing until 70 DAT and was decreased at 84 DAT. The predatory insects were generally more specialists in terms of prey species compared to spiders. Therefore, at approaching to harvest when the number of herbivore insects decreased, the predatory insects also decreased. Such a phenomenon frequently happened in specialist predatory arthropod because the population of the predator depended on the fluctuated population of their prey which is called as a functional response (Karenina et al. 2019). 
Table 5. Characteristic of predatory insect community in rice field sprayed with bioinsecticides (. B. bassiana, M. anisopliae, and C. militaris) and abamectin

\begin{tabular}{|c|c|c|c|c|}
\hline Characteristic of spider community & B. bassiana & M. anisopliae & C. militaris & Abamectin \\
\hline \multicolumn{5}{|l|}{14 days old rice } \\
\hline Abundance (individual/hill) & 1.00 & 0.60 & 0.20 & 0.80 \\
\hline Biodiversity index (H') & 1.33 & 1.09 & 0.00 & 0.00 \\
\hline Dominance index (D) & 0.40 & 0.33 & 1.00 & 0.25 \\
\hline Evenness index (E) & 0.96 & 1.00 & 0.00 & 0.00 \\
\hline \multicolumn{5}{|l|}{28 days old rice } \\
\hline Abundance (individual/hill) & 1.60 & 1.20 & 1.40 & 0.80 \\
\hline Biodiversity index $\left(\mathrm{H}^{\prime}\right)$ & 1.21 & 1.56 & 0.55 & 1.38 \\
\hline Dominance index (D) & 0.25 & 0.33 & 0.28 & 0.25 \\
\hline Evenness index (E) & 0.67 & 0.96 & 0.34 & 1.00 \\
\hline \multicolumn{5}{|l|}{42 days old rice } \\
\hline Abundance (individual/hill) & 2.60 & 1.80 & 1.60 & 1.00 \\
\hline Biodiversity index (H') & 1.94 & 1.88 & 1.66 & 1.66 \\
\hline Dominance index (D) & 0.15 & 0.22 & 0.37 & 0.40 \\
\hline Evenness index (E) & 0.88 & 0.97 & 0.93 & 1.20 \\
\hline \multicolumn{5}{|l|}{56 days old rice } \\
\hline Abundance (individual/hill) & 2.80 & 2.60 & 2.40 & 1.80 \\
\hline Biodiversity index $\left(\mathrm{H}^{\prime}\right)$ & 1.94 & 1.81 & 1.86 & 1.83 \\
\hline Dominance index (D) & 0.28 & 0.30 & 0.25 & 0.33 \\
\hline Evenness index (E) & 0.93 & 0.93 & 0.95 & 0.94 \\
\hline \multicolumn{5}{|l|}{70 days old rice } \\
\hline Abundance (individual/hill) & 2.60 & 2.80 & 2.20 & 1.60 \\
\hline Biodiversity index $\left(\mathrm{H}^{\prime}\right)$ & 1.60 & 1.90 & 1.67 & 1.49 \\
\hline Dominance index (D) & 0.30 & 0.28 & 0.27 & 0.37 \\
\hline Evenness index (E) & 0.89 & 0.91 & 0.93 & 0.92 \\
\hline \multicolumn{5}{|l|}{84 days old rice } \\
\hline Abundance (individual/hill) & 0.20 & 2.80 & 3.00 & 1.40 \\
\hline Biodiversity index (H') & 1.95 & 2.06 & 1.69 & 1.54 \\
\hline Dominance index (D) & 0.23 & 0.21 & 0.33 & 0.28 \\
\hline Evenness index $(\mathrm{E})$ & 0.93 & 0.94 & 0.87 & 0.96 \\
\hline \multicolumn{5}{|l|}{ Total } \\
\hline Abundance (individual/hill) & 13.2 & 11.8 & 9.8 & 7.4 \\
\hline Biodiversity index (H') & 2.25 & 2.27 & 2.11 & 2.25 \\
\hline Dominance index (D) & 0.91 & 0.89 & 0.88 & 0.94 \\
\hline Evenness index $(\mathrm{E})$ & 0.22 & 0.23 & 0.28 & 0.21 \\
\hline
\end{tabular}

The community of spider and predatory insects in the plot of B. bassiana tent to more similar to the community in plots of bioinsecticide $M$. anisopliae and $C$. militaris compared to that in the abamectin plot. This showed that the effect of the application of three entomopathogenic fungal bioinsecticides on the predator communities was not significantly different. The low community similarity between the bioinsecticide and the abamectin because the abamectin could reduce the abundance of spiders and predatory insects. There have been a lot of reports of the decrease of abundance and species diversity of spiders (Preetha et al. 2010) and predatory insects (Salachna et al. 2020) due to the application of abamectin containing organophosphate (Bai and Ogbourne 2016). In this research, abamectin as an active ingredient is a stomach poison and toxic against insect species of Menochilus sexmaculatus (Azod et al. 2016) and spider species of $P$. pseudoannulata (Baehaki et al. 2017).

Guild group made based on function correspondence of arthropods i.e. herbivore insects, neural insects, predators, and parasitoids. For one rice cropping season, there was a tendency that the abundance of all guilds group were lower in the abamectin plot. Interestingly, the abundance of predator was always more dominant in plots sprayed with the entomopathogenic fungal bioinsecticide compared to those of herbivore insects, neutral insects, and parasitoid. Neutral insects were not found in the synthetic insecticide plot. Thus phenomenon showed that predator guild was more tolerant to the entomopathogenic fungal bioinsecticide ( Firouzbakht et al. 2015; Bayissa et al. 2016; Gholamzadeh-Chitgar et al. 2017), while abamectin tent to reduce the abundance of predators, herbivore insects, neutral insects and parasitoids (Prabawati et al. 2019; Hanif et al. 2020). Among the three entomopathogenic fungi, there was a tendency that the abundance of the predators in plot sprayed with the bioinsecticide of $C$. militaris was higher than that in plots of B. bassiana and M. anisopliae. Therefore, predator arthropods tend to be more tolerant of C. militaris than of B. bassiana and M. anisopliae. 
Table 6. Matrix of similarity (Index Sorensen) of spider community in rice field sprayed with bioinsecticides (B. bassiana, M. anisopliae, and C. militaris) and abamectin

\begin{tabular}{|c|c|c|c|c|c|}
\hline Rice ages & Treatments & B. bassiana & M. anisopliae & C. militaris. & Abamectin \\
\hline \multirow{4}{*}{14 days } & B. bassiana & 1 & & & \\
\hline & M. anisopliae & 0.33 & 1 & & \\
\hline & C. militaris. & 0.25 & 0.00 & 1 & \\
\hline & Abamectin & 0.25 & 0.00 & 0.50 & 1 \\
\hline \multirow{4}{*}{28 days } & B. bassiana & 1 & & & \\
\hline & M. anisopliae & 0.18 & 1 & & \\
\hline & C. militaris. & 0.55 & 0.17 & 1 & \\
\hline & Abamectin & 0.29 & 0.25 & 0.25 & 1 \\
\hline \multirow{4}{*}{42 days } & B. bassiana & 1 & & & \\
\hline & M. anisopliae & 0.40 & 1 & & \\
\hline & C. militaris. & 0.48 & 0.42 & 1 & \\
\hline & Abamectin & 0.40 & 0.31 & 0.43 & 1 \\
\hline \multirow{4}{*}{56 days } & B. bassiana & 1 & & & \\
\hline & M. anisopliae & 0.58 & 1 & & \\
\hline & C. militaris. & 0.31 & 0.40 & 1 & \\
\hline & Abamectin & 0.40 & 0.43 & 0.50 & 1 \\
\hline \multirow{4}{*}{70 days } & B. bassiana & 1 & & & \\
\hline & M. anisopliae & 0.67 & 1 & & \\
\hline & C. militaris. & 0.32 & 0.64 & 1 & \\
\hline & Abamectin & 0.22 & 0.33 & 0.32 & 1 \\
\hline \multirow{4}{*}{84 days } & B. bassiana & 1 & & & \\
\hline & M. anisopliae & 0.73 & 1 & & \\
\hline & C. militaris. & 0.54 & 0.67 & 1 & \\
\hline & Abamectin & 0.59 & 0.50 & 0.44 & 1 \\
\hline \multirow{4}{*}{ TOTAL } & B. bassiana & 1 & & & \\
\hline & M. anisopliae & 0.76 & 1 & & \\
\hline & C. militaris. & 0.77 & 0.84 & 1 & \\
\hline & Abamectin & 0.49 & 0.60 & 0.56 & 1 \\
\hline
\end{tabular}

Table 7. Similarity of predatory insect community in rice field sprayed with bioinsecticides (B. bassiana, M. anisopliae, and C. militaris) and abamectin

\begin{tabular}{|c|c|c|c|c|c|}
\hline Rice ages & Treatments & B. bassiana & M. anisopliae & C. militaris. & Abamectin \\
\hline \multirow{5}{*}{14 days } & B. bassiana & 1 & & & \\
\hline & M. anisopliae & 0.50 & 1 & & \\
\hline & C. militaris. & 0.33 & 0.50 & 1 & \\
\hline & Abamectin & 0.22 & 0.00 & 0.00 & 1 \\
\hline & B. bassiana & 1 & & & \\
\hline \multirow{4}{*}{28 days } & M. anisopliae & 0.57 & 1 & & \\
\hline & C. militaris. & 0.53 & 0.31 & 1 & \\
\hline & Abamectin & 0.33 & 0.20 & 0.18 & 1 \\
\hline & B. bassiana & 1 & & & \\
\hline \multirow{4}{*}{42 days } & M. anisopliae & 0.73 & 1 & & \\
\hline & C. militaris. & 0.76 & 0.82 & 1 & \\
\hline & Abamectin & 0.44 & 0.57 & 0.46 & 1 \\
\hline & B. bassiana & 1 & & & \\
\hline \multirow{3}{*}{56 days } & M. anisopliae & 0.89 & 1 & & \\
\hline & C. militaris. & 0.69 & 0.88 & 1 & \\
\hline & Abamectin & 0.70 & 0.64 & 0.76 & 1 \\
\hline \multirow{4}{*}{70 days } & B. bassiana & 1 & & & \\
\hline & M. anisopliae & 0.74 & 1 & & \\
\hline & C. militaris. & 0.75 & 0.72 & 1 & \\
\hline & Insecticide & 0.57 & 0.55 & 0.74 & 1 \\
\hline \multirow{4}{*}{84 days } & B. bassiana & 1 & & & \\
\hline & M. anisopliae & 0.89 & 1 & & \\
\hline & C. militaris. & 0.71 & 0.76 & 1 & \\
\hline & Abamectin & 0.50 & 0.67 & 0.64 & 1 \\
\hline \multirow{4}{*}{ Total } & B. bassiana & 1 & & & \\
\hline & M. anisopliae & 0.91 & 1 & & \\
\hline & C. militaris. & 0.85 & 0.91 & 1 & \\
\hline & Abamectin & 0.66 & 0.77 & 0.79 & 1 \\
\hline
\end{tabular}


It could be concluded that the abundance and species diversity of arthropod predators inhabiting freshwater swamp sprayed with the bioinsecticides of B. bassiana, $M$. anisopliae, and $C$. militaris did not decrease, while the population of herbivore insects tent to decrease to the same level as its decrease in the abamectin plot. So that, the bioinsecticides of $B$. bassiana, M. anisopliae, and $C$. militaris did not decrease the abundance and species diversity of predatory arthropods (non-target arthropods) but could decrease the herbivore insect population.

\section{ACKNOWLEDGEMENTS}

This research was funded by Program of Research Grant Based on Competence (HIKOM) with the budget year of 2018 according to the Director of Research and Community Service, Directorate of Research and Community Service (DRPM), Directorate-General for Research and Development, Ministry of Research, Technology, and Higher Education, Republic of Indonesia (Grant number: 093/SP2H/LT/DRPM/IV/2018) chaired by SH. Special thanks to Dr. Suwandi, a microbiologist from the Department of Plant Pest and Disease, Faculty of Agriculture, Universitas Sriwijaya, Palembang, Indonesia for the identification of the fungi.

\section{REFERENCES}

Amzah B, Jajuli R, Jaafar NAI, Jamil SZ, Hamid SNAA, Zulkfili NI, Ismail NA, Kadir AA, Ariff EEE, Baki R. 2018. Application of ecological engineering to increase arthropod's diversity in rice field ecosystem. Malays Appl Biol 47 (5): 1-7.

Ayudya DR, Herlinda S, Suwandi S. 2019. Insecticidal activity of culture filtrates from liquid medium of Beauveria bassiana isolates from South Sumatra (Indonesia) wetland soil against larvae of Spodoptera litura. Biodiversitas 20 (8): 2101-2109.

Azod F, Shahidi NS, Mahdian K, Smagghe G. 2016. Lethal and sublethal effects of spirotetramat and abamectin on predatory beetles Menochilus sexmaculatus via prey Agonoscena pistaciae exposure, important for integrated pest management in pistachio orchards. Belgian J Zool 146 (2): 113-122.

Baehaki SE, Surahmat EC, Susetyo A, Senn R. 2017. Toxicity and persistence of insecticides to rove beetle Paederus fuscipes and wolf spider Lycosa pseudoannulata using semi field method. J Agric Vet Sci 4 (9): 331-337.

Bai SH, Ogbourne S. 2016. Chemosphere eco-toxicological effects of the avermectin family with a focus on abamectin and ivermectin. Chemosphere 154: 204-214.

Barrion A, Litsinger J. 1995. Riceland spiders of South and Southeast Asia. Entomology Division, International Rice Research Institute, Los Banos, Philippines.

Bayissa W, Ekesi S, Mohamed SA, Kaaya GP, Wagacha M, Hanna R, Maniania NK. 2016. Interactions among vegetable infesting aphids, the fungal pathogen Metarhizium anisopliae (Ascomycota: Hypocreales) and the predatory coccinellid Cheilomenes lunato (Coleoptera: Coccinellidae). J Biocontrol Sci Technol 26 (2): 274290.

Chaubey SN, Yadav PR. 2017. Studies on habit and habitat, external morphology, feeding capacity and prey preference of jumping spider Menemerus semilimbatus (Simon). J Exp Zool 20 (2): 729-732.

Chinniah C, Ravikumar A, Kalyanasundaram M, Parthiban P. 2016. Field evaluation of Metarhizium anisopliae liquid formulation (BioMagic ( ) against brown planthopper, Nilaparvata lugens Stal. on rice. J Biopest 9 (2): 211-219.

Chitgar MG, Hajizadeh J, Ghadamyari M, Karimi MA, Hoda H. 2017.
Effect of sublethal concentration of Beauveria bassiana fungus on demographic and some biochemical parameters of predatory bug, Andrallus spinidens Fabricius (Hemiptera: Pentatomidae) in laboratory conditions. Trakia J Sci 15 (2): 160-167.

Emami F, Alichi M, Minaei K. 2013. Interaction between the entomopathogenic fungus Beauveria bassiana (Ascomycota: Hypocreales) and the parasitoid wasp, Aphidius colemani Viereck (Hymenoptera: Braconidae). J Entomol Acarol Res 45 (4): 14-17.

Firouzbakht H, Zibaee A, Hoda H, Sohani MM. 2015. Virulence determination of Beauveria bassiana isolates on a predatory Hemipteran, Andrallus spinidens Fabricius (Hemiptera: Pentatomidae). Acta Phytopathol Entomol Hung 50 (1): 115-125.

Gholamzadeh-Chitgar M, Hajizadeh J, Ghadamyari M, Karimi-Malati A, Hoda H. 2017. Effect of sublethal concentration of Beauveria bassiana fungus on demographic and some biochemical parameters of predatory bug, Andrallus spinidens Fabricius (Hemiptera: Pentatomidae) in laboratory conditions. Trakia J Sci 15 (2): 160-167.

Girish VP, Balikai RA. 2015. Efficacy of botanicals, biopesticides and insecticide molecules against ear head bug, Leptocorisa acuta (Thunberg) in paddy and their effect on yield. J Exp Zool India 18 (2): $943-946$.

Gullan PJ, Cranston PS. 2014. The Insects: An Outline of Entomology. 5th ed.. J Wiley \& Sons, Ltd., London, UK.

Gustianingtyas M, Herlinda S, Suwandi, Suparman, Hamidson H, Hasbi, Setiawan A, Verawaty M, Elfita, Arsi. 2020. Toxicity of entomopathogenic fungal culture filtrate of lowland and highland soil of South Sumatra (Indonesia) against Spodoptera litura larvae. Biodiversitas 21 (5): 1839-1849.

Hanif KI, Herlinda S, Irsan C, Pujiastuti Y, Prabawati G, Hasbi, Karenina T. 2020. The impact of bioinsecticide overdoses of Beauveria bassiana on species diversity and abundance of not targeted arthropods in South Sumatra (Indonesia) freshwater swamp paddy. Biodiversitas 21 (5): 2124-2136.

Heinrichs EA, Nwilene FE, Stout M, Hadi BAR, Freitas T. 2017. Rice Insect Pests and Their Management. Burleigh Dodds Science Publishing, London.

Herlinda S, Yudha S, Thalib R, Khodijah, Suwandi, Lakitan B, Verawaty M. 2018. Species richness and abundance of spiders inhabiting rice in fresh swamps and tidal lowlands in South Sumatra, Indonesia. J ISSAAS 24 (1): 82-93.

Herlinda S, Karenina T, Irsan C, Pujiastuti Y. 2019a. Arthropods inhabiting flowering non-crop plants and adaptive vegetables planted around paddy fields of freshwater swamps of South Sumatra, Indonesia. Biodiversitas 20 (11): 3328-3339.

Herlinda S, Yusticia SR, Irsan C, Hadi BAR, Lakitan L, Verawaty M, Hasbi. 2019b. Abundance of arthropods inhabiting canopy of rice cultivated using different planting methods and varieties. J Biopest 12 (1): 7-18.

Herlinda S, Alesia M, Susilawati, Irsan C, Hasbi, Suparman, Anggraini E, Arsi. 2020. Impact of mycoinsecticides and abamectin applications on species diversity and abundance of aquatic insects in rice fields of freshwater swamps of South Sumatra, Indonesia. Biodiversitas 21 (7): 3076-3083.

Humber, R.A. 2012. Identification of entomopathogenic fungi. In: Lacey LA (ed). Manual of Techniques in Invertebrate Pathology. Academic Press, London,UK.

Ivantsova EA, Novochadov VV, Onistratenko NV, Postnova MV. 2017. Ecological aspects of phytosanitary optimization of arid agrobiocenoses of the south of Russia. Bulg J Agric Sci 23 (5): 834842.

Karenina T, Herlinda S, Irsan C, Pujiastuti Y. 2019. Abundance and species diversity of predatory arthropods inhabiting rice of refuge habitats and synthetic insecticide application in freshwater swamps in South Sumatra, Indonesia. Biodiversitas 20 (8): 2375-2387.

Karenina T, Herlinda S, Irsan C, Pujiastuti Y. 2020. Arboreal entomophagous arthropods of rice insect pests inhabiting adaptive vegetables and refugia in freshwater swamps of South Sumatra. Agrivita 42 (2): 1-10.

Kavallieratos NG, Athanassiou GG, Kontodimas MM, Aountala K, Demetrius C. 2015. Evaluation of the entomopathogenic fungi Beauveria bassiana, Metarhizium anisopliae, and Isaria fumosorosea for control of Sitophilus oryzae. J Food Protect 77 (1): 87-93. 
Kin PK, Azmi WA, Kamarudin N, Ali SRA, Moslim R. 2017. The occurrence of entomopathogenic fungi on mineral and peat soils in Peninsular Malaysia. Am J Agric Biol Sci 12 (1): 1-12.

Kryukov VY, Yaroslavtseva ON, Dubovskiy IM, Tyurin MV, Kryukova NA, Glupov VV. 2014. Insecticidal and immunosuppressive effect of Ascomycete Cordyceps militaris on the larvae of the Colorado Potato Beetle Leptinotarsa decemlineata. Ecol 41 (3): 276-283.

Lami F, Masetti A, Neri U, Lener M, Staiano G, Arpai S, Burgio G. 2016 Diversity of Coccinellidae in ecological compensation areas of Italy and overlap with maize pollen shedding period. Bull Insect 69 (1): 49 57.

Lee SJ, Yu JS, Nai YS, Parker BL, Skinner M, Kim JS. 2015. Beauveria bassiana sensu lato granules for management of brown planthopper, Nilaparvata lugens in rice. Bio Control 60 (2): 263-270.

Li M, Lin H, Li S, Xu A, Feng M. 2012. Efficiency of entomopathogenic fungi in the control of eggs of the brown planthopper Nilaparvata lugens Stål (Homoptera: Delphacidae). Afr J Microbiol Res 6 (44): 7162-7167.

Li M, Li S, Xu A, Lin H, Chen D, Wang H. 2014. Selection of Beauveria isolates pathogenic to adults of Nilaparvata lugens. J Insect Sci 14(1): $1-12$.

Liu SF, Wang GJ, Nong XQ, Liu B, Wang MM, Li SL, Cao GC, Zhang ZH. 2017. Entomopathogen Metarhizium anisopliae promotes the early development of peanut root. Plant Protect Sci. 53 (2): 101-107.

Lopez DC, Zhu-Salzman K, Ek-Ramos MJ, Sword GA. 2014. The entomopathogenic fungal endophytes Purpureocillium lilacinum (formerly Paecilomyces lilacinus) and Beauveria bassiana negatively affect cotton aphid reproduction under both greenhouse and field conditions. PLoS ONE 9 (8): e103891. DOI 10.1371/journal.pone.0103891.

Ma T, Wang H, Liang S, Xiao Q, Cao P, Chen X, Niu Y, He Y, Sun Z, Wen X, Wang C. 2019. Effects of soil-treatment with fungal biopesticides on pupation behaviors, emergence success and fitness of tea geometrid, Ectropis grisescens (Lepidoptera: Geometridae). J Asia-Pac Entomol 22 (1): 208-214.

Magurran AE. 2004. Measuring Biological Diversity. Blackwell Science, Oxford.

Mweke A, Akutse KS, Ulrichs C, Fiaboe KKM, Maniania NK, Ekesi S. 2019. Efficacy of aqueous and oil formulations of a specific Metarhizium anisopliae isolate against Aphis craccivora Koch, 1854 (Hemiptera: Aphididae) under field conditions. J Appl Entomol 143 (10): 1182-1192.
Prabawati G, Herlinda S, Pujiastuti Y. 2019. The abundance of canopy arthropods in South Sumatra (Indonesia) freshwater swamp main and ratooned rice applied with bioinsecticides and synthetic insecticide. Biodiversitas 20 (10): 2921-2930.

Preetha G, Stanley J, Suresh S, Samiyappan R. 2010. Risk assessment of insecticides used in rice on mirid bug, Cyrtorhinus lividipennis Reuter, the important predator of brown planthopper, Nilaparvata lugens (Stal). Chemosphere 80 (5): 498-503.

Rachmawati R, Kinoshita H, Nihira T. 2018. Production of insect toxin beauvericin from entomopathogenic fungi Cordyceps militaris by heterologous expression of global regulator. Agrivita 40 (1): 177-184.

Safitri A, Herlinda S, Setiawan A. 2018. Entomopathogenic fungi of soils of freshwater swamps, tidal lowlands, peatlands, and highlands of South Sumatra, Indonesia. Biodiversitas 19 (6): 2365-2373.

Salachna A, Olearczyk Z. 2020. Assessment of the ecological potential of the Sola River Cascade on the basis of the selected biological indicators. J Ecol Eng 21 (1): 81-87.

Scorsetti AC, Pelizza, S, Fogel MN, Vianna F, Schneider MI. 2017. Interactions between the entomopathogenic fungus Beauveria bassiana and the Neotropical predator Eriopis connexa (Coleoptera: Coccinellidae): Implications in biological control of pest. J Plant Protec Res 57 (4):389-395.

Seiedy M, Heydari S, Tork M. 2015. Orientation of Hippodamia variegata (Coleoptera: Coccinellidae) to healthy and Beauveria bassiana-infected Aphis fabae (Hemiptera: Aphididae) in an olfactometer system. Turk J Zool 39: 53-58.

Shrestha B, Tanaka E, Hyun MW, Han JG, Kim CS, Jo JW, Han SK, Oh J, Sung GH. 2016. Coleopteran and lepidopteran hosts of the entomopathogenic genus Cordyceps sensu lato. J Mycol 2016: 1-14.

Sumikarsih E, Herlinda S, Pujiastuti Y. 2019. Conidial density and viability of Beauveria bassiana isolate from Java and Sumatra and their virulence against Nilaparvata lugens at different temperatures. Agrivita 41 (2): 335-349.

Suwandi, Ammar M, Irsan C. 2012. Application of extract compost increased yield and suppressed the diseases of ratoon rice crop in tidal swamp of Banyuasin Regency. Jurnal Lahan Suboptimal 1 (2): 116122. [Indonesia]

Zheng P, Xia Y, Xiao G, Xiong C, Hu X, Zhang S, Zheng H, Huang Y, Zhou Y, Wang S, Zhao GP, Liu X, StLeger RJ, Wang C. 2011. Genome sequence of the insect pathogenic fungus Cordyceps militaris, a valued traditional Chinese medicine. Genome Biol 12 (11): R116. DOI: 10.1186/gb-2011-12-11-r116. 